Удк 616.314-007.21-085.461-085.454.1-003.96

\title{
ПОРІВНЯЛЬНА ОЦІНКА ЯКОСТІ ВІДНОВЛЕННЯ ЖУВАЛЬНОЇ ЕФЕКТИВНОСТІ ПРИ ЛІКУВАННІ ПАЦІЄНТІВ ЗНІМНИМИ ОРТОПЕДИЧНИМИ КОНСТРУКЦІЯМИ, ВИГОТОВЛЕНИМИ ЗА РІЗНИМИ ЛАБОРАТОРНИМИ ТЕХНОЛОГІЯМИ, НА ПІДСТАВІ ДАНИХ ЕЛЕКТРОМІОГРАФІЧНОГО ДОСЛІДЖЕННЯ
}

\author{
П.С. Запара, І.В. Янішен, О.Л. Федотова \\ ХаркіВський національний медичний уніВерситет
}

В Україні виготовлення знімних пластинкових протезів з жорстким базисом сягає 80\%. За даними літератури, від 20 до 26\% пацієнтів не користуються знімними протезами, а 37\% - незадоволені якістю ортопедичного лікування ними. Крім того, в $52 \%$ випадків знімні конструкції мають недостатню фріксацію та стабілізацію на протезних ложах. У $64 \%$ пацієнтів під базисами протезів розвиваються захворювання слизової оболонки травматичної етіології (В.А. Лабунець).

Тому дослідження процесу адаптації до нового протезу важливо для розуміння засобів контролю жувальної мускулатури і може дати цінну інформацію для визначення подальшого шляху вирішення проблем, що заважають хворим досягнути повної адаптації до протезів. Аналіз електроміографрічної активності і кінетики жувальних рухів потрібен для розуміння системи рухової активності та жувальної ефективності.

Метою дослідження $є$ порівняльна характеристика терміну/якості адаптації пацієнтів до знімних пластинкових ортопедичних конструкцій, виготовлених за різною лабораторною технологією, за допомогою електроміографічного дослідження жувальних м'язів.

Для досягнення поставленої мети було обстежено та проліковано 80 пацієнтів з частковою втратою зубів у віці 45-65 років, яким показано заміщення дефектів зубних рядів частковими знімними ортопедичними конструкціями. Пацієнти, що брали участь у дослідженні, були розділені на три групи: пацієнтам першої групи протези було виготовлено з акрилової пластмаси термоінжекційним методом; пацієнтам другої групи протези були виготовлені з акрилової пластмаси гарячої полімеризації компресійним методом; третю групу складали пацієнти, протези яким були виготовлені з нової вітчизняної акрилової пластмаси методом вільного лиття з послідуючою полімеризацією під тиском.

Головним показником адаптації пацієнтів нашого дослідження $є$ нормалізація фрункції жування, що оцінюється за допомогою електроміографічного аналізу жувальних м'язів.

Виходячи с показників середнього коефріцієнта відношення показників електроміографрічного дослідження, ми можемо стверджувати, що адаптація пацієнтів групи, де протези виготовлялися за технологією лиття з послідуючою полімеризацією під тиском, є більш послідовною та якіснішою, ніж у груп пацієнтів, де використовувалися інші лабораторні технології виготовлення знімних протезів.

Таким чином, електроміографрічне дослідження показало, що методика лиття з послідуючою полімеризацієюпід тиском при виготовленні знімних пластинковихпротезів більш якісно відновлює жувальну функцію та спонукає на нормалізацію та адаптацію м'язової системи до жування. Ключові слова: знімний протез, адаптація, електроміографрія, лабораторні технології.

Актуальність. Останнім часом, у зв'язку зі збільшенням у складі населення нашої країни осіб похилого віку зростає потреба в знімних пластинкових протезах при часткових десектах зубних рядів і при повній відсутності зубів. Кількість пацієнтів, яким показані такі конструкції зубних протезів, становить велику питому вагу в загальній кількості пацієнтів, що потребують протезування.
В Україні виготовлення знімних пластинкових протезів з жорстким базисом сягає $80 \%$. За даними літератури, від 20 до $26 \%$ пацієнтів не користуються знімними протезами, а $37 \%$ - незадоволені якістю ортопедичного лікування ними. Крім того, в $52 \%$ випадків знімні конструкції мають недостатню ффіксацію та стабілізацію на протезних ложах. У $64 \%$ пацієнтів під базисами протезів розвивають- 
ся захворювання слизової оболонки травматичної етіології [1, 2].

Тому дослідження процесу адаптації до нового протезу важливо для розуміння засобів контролю жувальної мускулатури і може дати цінну інформацію для визначення подальшого шляху вирішення проблем, що заважають хворим досягнути повної адаптації до протезів. Аналіз електроміографічної активності і кінетики жувальних рухів потрібен для розуміння системи рухової активності.

Електроміографрічне дослідження (ЕМГ) м'язів щелепно-лицьової ділянки $€$ одним 3 провідних методів діагностики в стоматологічній практиці в усьому світі. ЕМГ дослідження жувальних м'язів дозволяють визначити зміни функціонального стану м'язів у фазі жувального руху на стадіях адаптації до знімних ортопедичних конструкцій та є об'єктивним підтвердженням якості проведеного ортопедичного лікування. Метод електроміографрії безболісний і нешкідливий, що дозволяє активно використовувати цей спосіб для визначення біоелектричної активності жувального апарату.

Метою дослідження $€$ порівняльна характеристика терміну/якості адаптації пацієнтів до знімних пластинкових ортопедичних конструкцій, виготовлених за різною лабораторною технологією, за допомогою електроміографрічного дослідження жувальних м'язів.

Матеріали та методи. Для досягнення поставленої мети було обстежено та проліковано 80 пацієнтів з частковою втратою зубів у віці 45-65 років, яким показано заміщення дефектів зубних рядів частковими знімними ортопедичними конструкціями. Пацієнти, що брали участь у дослідженні, були розділені на три групи: пацієнтам першої групи протези було виготовлено з акрилової пластмаси термоінжекційним методом; пацієнтам другої групи - 3 акрилової пластмаси гарячої полімеризації компресійним методом; третю групу складали пацієнти, протези яким були виготовлені з нової вітчизняної акрилової пластмаси методом вільного лиття з послідуючою полімеризацією під тиском.

Контроль ефективності лікування пацієнтів включає об'єктивну оцінку фрункціональних показників, що свідчитимуть про якість протезування під час поточного обстеження та рівень задоволення пацієнта протезуванням або, навпаки, наявності скарг. Головним показником адаптації пацієнтів нашого дослідження $€$ нормалізація функції жування, що оцінюється за допомогою електроміографрічного аналізу жувальних м'язів.

При електроміографрічному дослідженні жувальних м'язів було виявлено зміни функціональної активності жувальної мускулатури при ортопедичному лікуванні хворих з дефектами зубних рядів знімними конструкціями протезів, використовуючи різні технології для їх лабораторного виготовлення. Дослідження проводились на базі Харківського національного медичного університету - на кафедрі ортопедичної стоматології. Для цього проводили запис електроміограми за допомогою комп'ютерної нейрофізіологічної діагностичної системи «M-TEST». Умови були стандартні для всіх пацієнтів. В якості відвідних електродів використовувалися поверхневі, нашкірні, самоклеючі токоз'ємники. Реєструючий електрод накладали на рухові точки м'язів, індисерентні електроди розташовували ближче до місця прикріплення оних м'язів. Заземлюючий електрод був накладений на зап'ясті пацієнтів. Фільтрація низьких частот була встановлена на рівні 3 Гц, для високихчастот 10000 Гц, чутливість неперевищувала 500 мкВ, а опір 5 кОм. Реєстрація проводилася одночасно на 2-х каналах, з правого і лівого жувальних м'язів. Для більш повного дослідження жувальних м'язів, запис електроміограми проводився під час змикання зубних рядів в центральній оклюзії та під час проведення жувальної проби. Пацієнту пропонували розжувати ядро горіха вагою 800 мг (середня вага горіха), поки не з'явиться ресрлекс ковтання. ЕМГ проводили в день накладання протезу, через 7 днів та 1 місяць після протезування. Під час аналізу ЕМГ визначали: середню амплітуду при змиканні зубних рядів, середню амплітуду жування, час біоелектричної активності (БЕА) та час біоелектричного спокою (БЕС).

Результати та їх обговорення. В результаті проведених електроміограсрічних досліджень були отримані цифррові дані, що приведені у табл.

В день накладання знімних ортопедичних конструкцій показники були практично однакові у всіх групах, лише оцінка другої групи, де виготовлення часткового знімного протезу проводили компресійним методом, на 5\% була менше першої та третьої груп. Показники амплітуди при стисненні та жуванні склали відповідно 153,14 і 140,01 у пацієнтів першої групи; 161,1 і 149,5 у пацієнтів другої групи; 161,02 і 138,1 мкВ у пацієнтів третьої групи. Через тиждень після протезування амплітуда при стисненні та жуванні склала відповідно 180,24 та 160,18 мкВ у пацієнтів першої групи; 170,21 та 152,6 мкВ у пацієнтів другої групи; 210,03 та 159,1 мкВ у пацієнтів, протези яким були виготовлені литтєвим методом. Показники третьої групи на 19\% перевищували показники досліджуваних, на етапах лікування яких використовували термоінжекційний метод виготовлення часткових протезів, та на 16,5\% перевищувала показники другої групи, що використовували компресійний метод виготовлення протезу. Показники першої і третьої груп незначно різнились між собою. Через місяць після початку використання протезів пацієнтами амплітуда при стисненні та жуванні власне жувальних м'язів змінилась у позитивну сторону у всіх груп пацієнтів та склала відповідно по групам: 181,24 та 162,18 мкВ; 159,21 та 145,6 мкВ; 290,04 та 165,1 мкВ. Показники третьої групи значно перевищували цифрові дані першої та другої групи - на 38 та на $47 \%$ відповідно.

При проведенні порівняння лікування пацієнтів знімними пластинковими протезами, виготовленими за різними лабораторними технологіями, можемо відмітити, що найбільша жувальна ефективність у пацієнтів, що використовують протези, виготовлені литтєвим методом з полімеризацією під тиском 
Електроміографочне дослідження жуВальних м'язів

\begin{tabular}{|l|c|c|c|}
\hline \multirow{2}{*}{ Показник } & \multicolumn{3}{|c|}{ Термін виконання дослідження } \\
\cline { 2 - 4 } & 1 день & 7 день & 30 день \\
\hline \multirow{2}{*}{ Функціональна характеристика власне жувальних м'язів пацієнтів після протезування акриловими протезами } \\
виготовленими термоінжекційним методом (група 1) \\
\hline Амплітуда при стисненні, мкВ & 153,14 & 180,24 & 181,24 \\
\hline Амплітуда жування, мкВ & 140,01 & 160,18 & 162,18 \\
\hline БЕА, с & 0,24 & 0,28 & 0,30 \\
\hline БЕС, с & 0,44 & 0,48 & 0,50 \\
\hline Функціональна характеристика власне жувальних м'язів пацієнтів після протезування акриловими протезами \\
\hline виготовленими компресійним методом (група 2) \\
\hline Амплітуда при стисненні, мкВ & 161,1 & 170,21 & 159,21 \\
\hline Амплітуда жування, мкВ & 149,5 & 152,6 & 145,6 \\
\hline БЕА, с & 0,24 & 0,30 & 0,25 \\
\hline БЕС, с & 0,43 & 0,50 & 0,42 \\
\hline Функціональна характеристика власне жувальних м'язів пацієнтів після протезування акриловими протезами \\
\hline виговленими литтвим метод з послідуючою полімеризацією під тиском (група 3) \\
\hline Амплітуда при стисненні, мкВ & 161,02 & 210,03 & 290,04 \\
\hline Амплітуда жування, мкВ & 138,1 & 152,6 & 165,1 \\
\hline БЕА, с & 0,22 & 0,26 & 0,29 \\
\hline БЕС, с & 0,39 & 0,44 & 0,46 \\
\hline
\end{tabular}

290,04 $\pm 0,23$ мкВ. Не суттєво менша жувальна ефрективність у пацієнтів, протези яким були виготовлені за термоінжекційною методикою, $181,24 \pm 1,05$ мкВ, та найменший показник, де протези були виготовлені за компресійною методикою, - 159,21 1,03 мкВ, що відображено на графріку 1, що свідчить про високу якість адаптації та перебудову м'язової функції та міотатичних рефллексів пацієнтів, яким частковий знімний протез був виготовлений методом лиття з послідуючою полімеризацією під тиском (графріки 1a, 1б).

Наступним дослідженням була оцінка чергування фраз біоелектричної активності (БЕА) з фраза- ми біоелектричного спокою (БЕС). При реєстрації довільного жування ядра горіха на ЕМГ є чітке синхронне чергування фаз БЕА і БЕС.

Сила скорочення жувальних м'язів регулюється гінгіво-мускулярними рецепторами і рецепторами пародонту. Процеси збудження (БЕА) в них чергуються з процесами гальмування (БЕС). Фаза БЕА може бути рівною або менше фрази БЕС, це залежить від функціонального стану нервово-рецепторного апарату м'яких тканин, пародонту і жувальних м'язів.

БЕА, мс - середній період ділянки біоелектричної активності. Даний параметр розраховується як середня арифметична тривалість всіх ділянок

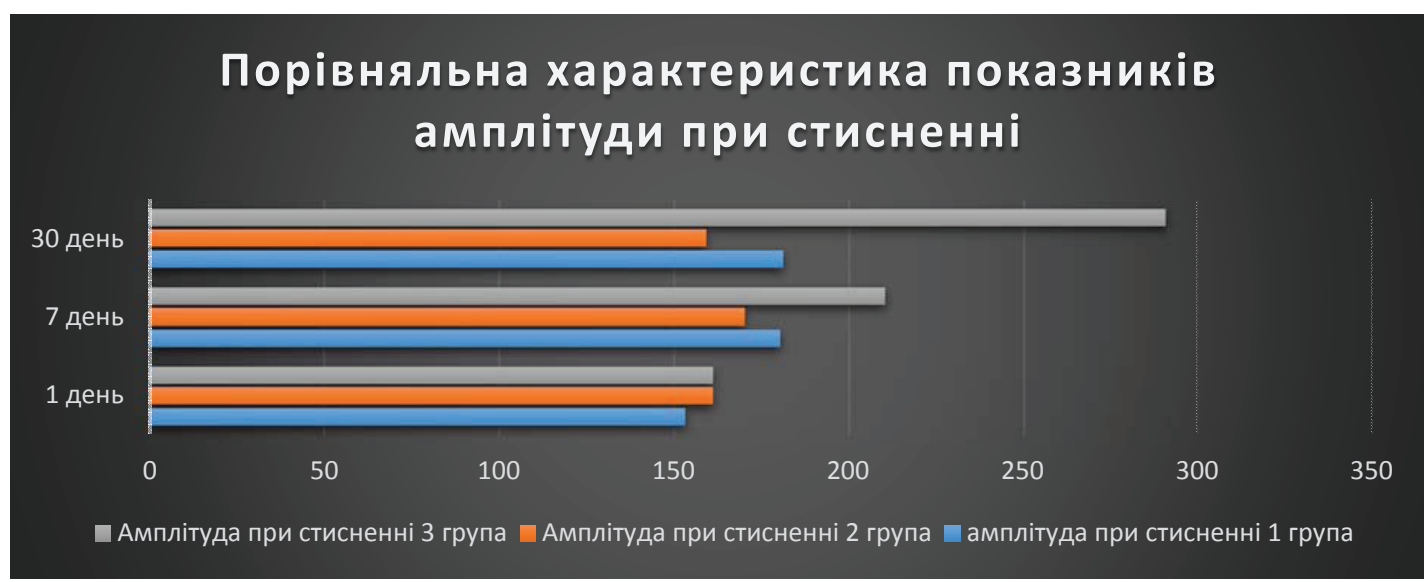

Грасрік 1a 


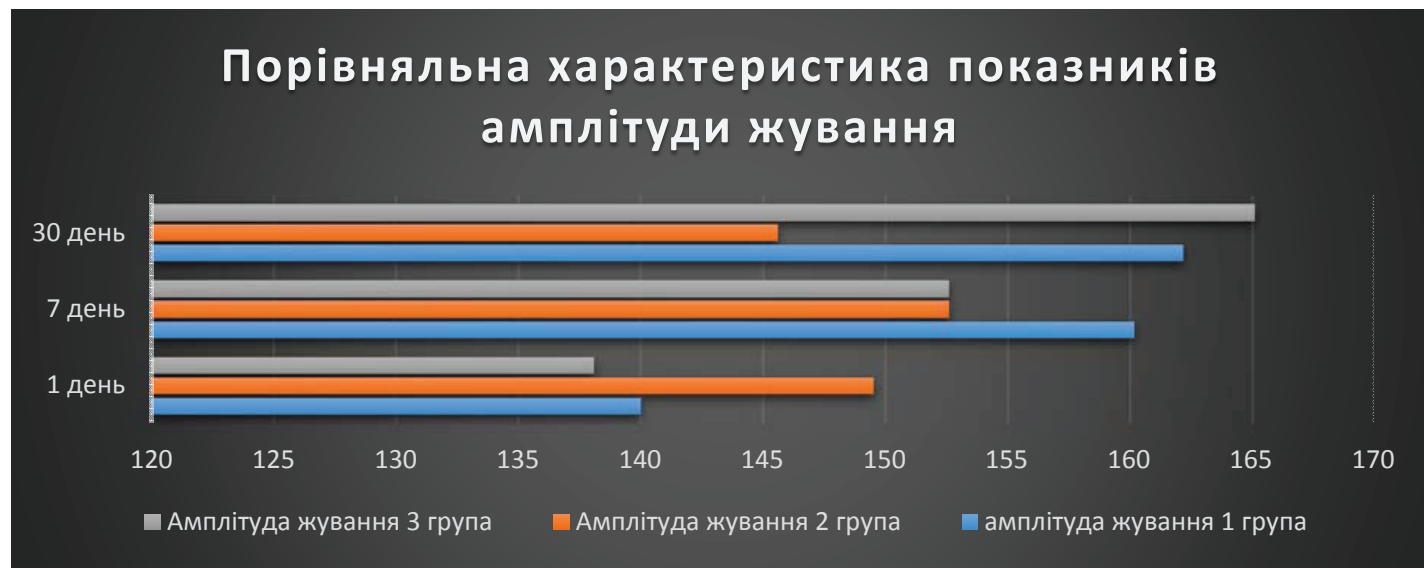

Грасрік 16

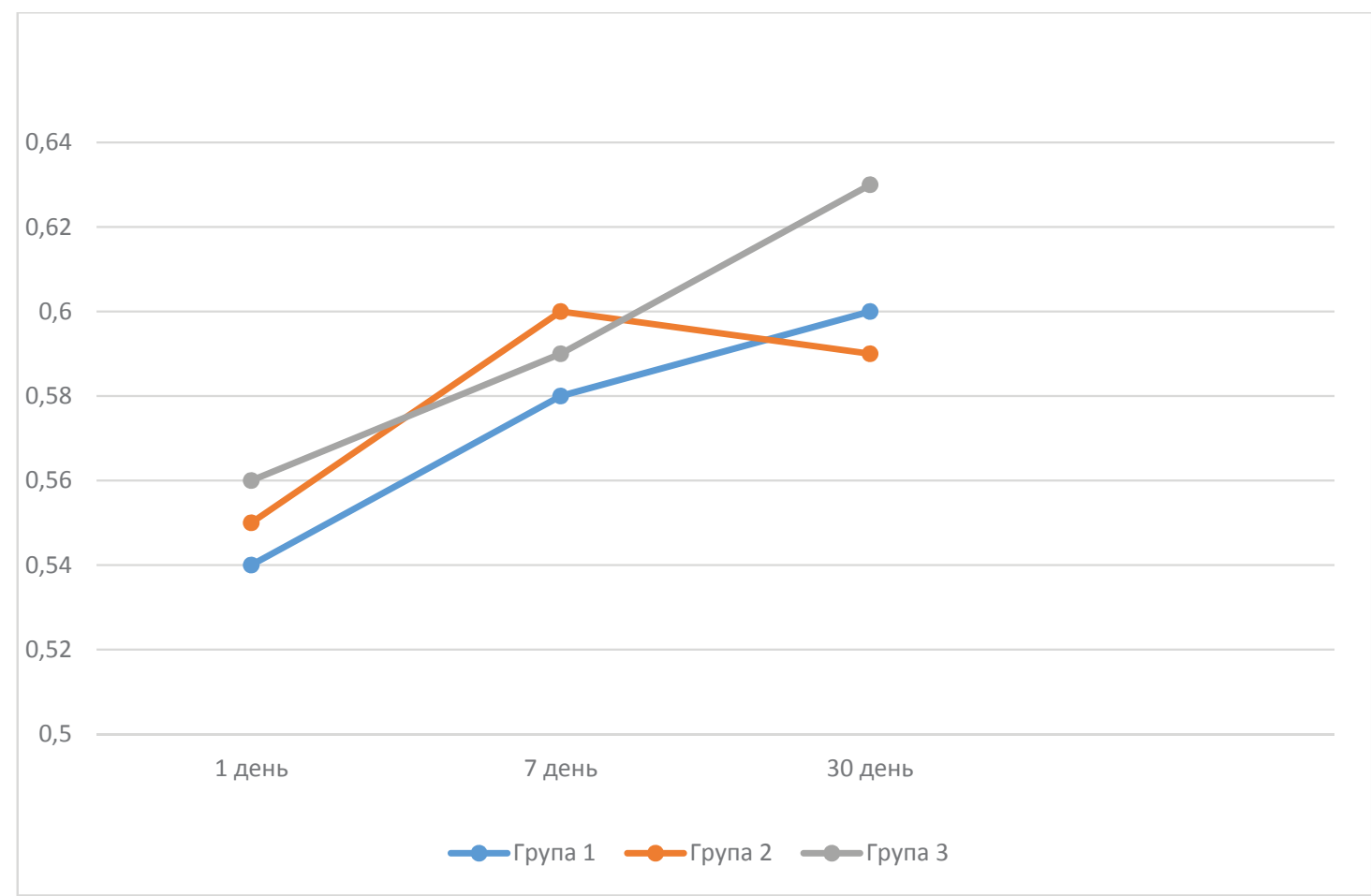

Графік 2. Графік порівняльної оцінки відношення фази БЕА до БЕС на різних термінах адаптації до часткових протезів,

виражений у коефіцієнті «К»

біоелектричної активності на одній ділянці аналізу. БЕС, мс - середній період ділянки біоелектричного спокою. Даний параметр розраховується як середня арифрметична тривалість всіх ділянок біоелектричного спокою на одній ділянці аналізу.

Фаза БЕА жувальних м'язів виникає в ритмі жувальних досліджень і відповідає їм. БЕА характеризується наростанням частоти і амплітуди біопотенціалів, які в середині фрази досягають своїх максимальних значень, після чого відбувається зниження їх величини і перехід в фазу БЕС, виражену на ЕМГ у вигляді прямої лінії на рівні ізоелектричної.

Для оцінки якості/терміну адаптації до виготовлених протезів ми обчислюємо відношення фрази біологічної активності до фази біологічного спокою (коесріцієнт К). Коефріцієнт К для жувальних м'язів при інтактних зубних рядах в нормі дорівнює в середньому 0,9. При частковій вторинній адентії, залежно від кількості відсутніх зубів, ці показники зменшуються до 0,4 (графрік 2).

Виходячи с показників середнього коефріцієнта відношення БЕА до БЕС ми можемо стверджувати, що 
адаптація пацієнтів групи 3, де протези виготовлялися за технологією лиття з послідуючою полімеризацією під тиском, є більш послідовною та якіснішою, ніж у групах 1 та 2.

Таким чином, ЕМГ дослідження показали, що методика лиття 3 послідуючою полімеризацією під тиском при виготовленні знімних пластинкових протезів більш якісно відновлює жувальну функцію та спонукає на нормалізацію та адаптацію м'язової системи до жування.

Використання вітчизняної литтєвої пластмаси в якості конструкційного матеріалу для виготовлення базису знімних протезів якісно підвищує ситуацію у термінах адаптації пацієнтів до знімних протезів, дозволяє більш комфортно ними користуватись, що суттєво покращує якість життя пацієнтів в цілому.

Література

1. Лабунец В. А. Влияние зубного эликсира «Экстравин-Дента» на состояние полости рта у пациентов со съемным протезированием / В.А. Лабунец, Н.В. Рожкова / / Вісник стоматології. - 2010. - № 3. - С. 64-67. - Режим доступу: http://nbuv.gov.ua/UJRN/VSL_2010_3_19.

2. Пискур В.В. Повторное протезирование при полной потере зубов / В.В. Пискур / / Современная стоматология. - 2005. - № 1. - С. 37-39.

3. Хватова В.А. Клиническая гнатология / В.А. Хватова. - М.: Медицина, 2008. - 296 с.

4. Ferrario V.F. An electromyographic investigation muscles symmetry in normo-occlusion subjects / V.F. Ferrario, C. Sforza, A. Colombo, V. Ciusa // Journal of oral rehabilitation. - 2000. - V. 27. - P. 33-40.

5. Klasser G.D. The clinical usefulness of surface electromyography in the diagnosis and treatment of temporomandibular disorders / G.D. Klasser, J.P. Okeson / / J. am. dent. assoc. - 2006. - V. 137. - P. 763-771.

6. Nnoaham K.E. Transcutaneous electrical nerve stimulation (TENS) for chronic pain / K.E. Nnoaham, J. Kumbang / / Cochrane database syst. rev. - 2008. - Vol. 16 (3). - CD003222.

7. Коваленко О.И. Сравнение современных материалов для базисов съемных зубных протезов / О.И. Коваленко, Д.В. Серебров / Матер. 6-й междунар. науч. конф. студ. и мол. уч. «Настоящее и будущее медицины». - Винница, 2009. - С. 116.

8. Гуринова Е.С. Полимерные материалы в стоматологии / Е.С. Гуринова, Т.Н. Соколова. - Витебск: ВГМУ, 2002. - C. 48-49.

9. Shigli K. Prosthetic status and treatment needs among patients attending the prosthodontic department in a dental institute in India / K. Shigli, M. Hebbal, G.S. Angadi / / Eur. J. Prosthodont Restor. Dent. - 2009. - Vol. $17(2)-$ P. 85-89.

\section{П.С. Запара, И.В. Янишен, Е.Л. Федотова}

\section{СРАВНИТЕЛЬНАЯ ОЦЕНКА КАЧЕСТВА ВОССТАНОВЛЕНИЯ ЖЕВАТЕЛЬНОЙ ЭФФЕКТИВНОСТИ ПРИ ЛЕЧЕНИИ ПАЦИЕНТОВ СЪЕМНЫМИ ОРТОПЕДИЧЕСКИМИ КОНСТРУКЦИЯМИ, ИЗГОТОВЛЕННЫМИ РАЗНЫМИ ЛАБОРАТОРНЫМИ ТЕХНОЛО- ГИЯМИ, НА ОСНОВАНИИ ДАННЫХ ЭЛЕКТРОМИОГРАФИЧЕСКИХ ИССЛЕДОВАНИЙ}

В Украине изготовление съемных пластиночных протезов с жестким базисом достигает 80\%. По данным литературы, от 20 до $26 \%$ пациентов не пользуются съемными протезами, а $37 \%$ - недовольны качеством ортопедического лечения ими. Кроме того, в $52 \%$ случаев съемные конструкции имеют недостаточную фиксацию и стабилизацию на протезных ложах. В $64 \%$ у пациентов под базисами протезов развиваются заболевания слизистой оболочки травматической этиологии (В.А. Лабунец). Поэтому исследования процесса адаптации к новому протезу важны для понимания средств контроля жевательной мускулатуры и могут дать ценную информацию для определения дальнейшего пути решения проблем, мешающих больным достичь полной адаптации к протезам. Анализ электромиографической активности и кинетики жевательных движений нужен для понимания системы двигательной активности и жевательной эффрективности.

Целью исследования является сравнительная характеристика терминов/качества адаптации пациентов к съемным пластиночным протезам, изготовленных с использованием различных лабораторных технологий, с помощью электромиографических исследований жевательных мышц.

Для достижения поставленной цели было обследовано и пролечено 80 пациентов с частичной потерей зубов в возрасте 45-65 лет, которым показано замещение дефектов зубных рядов частичными съемными ортопедическими конструкциями. Пациенты, участвовавшие в исследовании, были разделены на три группы: пациентам первой группы протезы были изготовлены из акриловой пластмассы термоинжекционным методом; пациентам второй группы - из акриловой пластмассы горячей полимеризации компрессионным методом; третью группу составляли пациенты, протезы которым были изготовлены из новой отечественной акриловой пластмассы методом свободного литья с последующей полимеризацией под давлением.

Главным показателем адаптации пациентов нашего исследования является нормализация функции жевания, что оценивается с помощью электромиографического анализа жевательных мышц.

Исходя из показателей среднего коэффицциента отношения показателей электромиографического исследования, мы можем утверждать, что адаптация пациентов группы, где протезы изготавливались по технологии 
литья с последующей полимеризацией под давлением, была более последовательной и качественной, чем у групп пациентов, где использовались другие лабораторные технологии изготовления съемных протезов.

Таким образом, ЭМГ исследования показали, что методика литья с последующей полимеризацией под давлением при изготовлении съемных пластиночных протезов более качественно восстанавливает жевательную функцию и способствует нормализации и адаптации мышечной системы к жеванию.

КлючеВые слова: съемный протез, адаптация, электромиография, лабораторные технологии.

\section{P.S Zapara, I.V. Yanishen, E.L. Fedotova}

\section{COMPARATIVE EVALUATION OF THE QUALITY OF THE RECOVERY OF CHEWING EFFECTIVENESS IN THE TREATMENT OF PATIENTS WITH REMOVABLE ORTHOPEDIC STRUCTURES, MADE ACCORDING TO VARIOUS LABORATORY TECHNOLOGIES, BASED ON DATA ELECTRO-MYOGRAPHIC RESEARCH}

In Ukraine, the manufacture of removable laminar dentures with a rigid base reaches $80 \%$. According to the literature, from 20 to $26 \%$ of patients do not use removable prostheses, and $37 \%$ are dissatisfied with the quality of orthopedic treatment with them. In addition, in $52 \%$ of cases, removable structures have insufficient fixation and stabilization on prosthetic beds. In $64 \%$ of patients, diseases of the mucous membrane of a traumatic etiology develop in the bases of prostheses (Labunets VA, 2010; Leus PA, 2013).

Therefore, research into the process of adaptation to a new prosthesis is important for understanding the means of controlling the chewing muscles and can provide valuable information for determining the further way to solve problems that prevent patients from achieving full adaptation to prostheses. Analysis of electromyographic activity and kinetics of chewing movements is necessary for understanding the system of motor activity and chewing efficiency.

The aim of the study is a comparative characteristic of the term / quality of adaptation of patients to removable laminar orthopedic structures made according to different laboratory technology, using an electromyographic study of the masticatory muscles.

To achieve this goal, 80 patients with partial tooth loss between the ages of 45-65 years were examined and who were shown to replace dentition defects with partial removable orthopedic structures. The patients participating in the study were divided into three groups: patients of the first group of prostheses were made of acrylic plastic using the thermo-injection method. Patients of the second group of prostheses were made of acrylic plastic of hot polymerization by compression method. The third group consisted of patients whose prostheses were made from new domestic acrylic plastic using the free casting method, followed by polymerization under pressure.

The main indicator of patient adaptation in our study is the normalization of the chewing function, which is assessed using electromyographic analysis of the masticatory muscles.

Based on the average ratio of the indicators of electromyographic research, we can argue that the adaptation of patients in the group where prostheses were made using casting technology followed by polymerization under pressure was more consistent and high-quality than in groups of patients using other laboratory technologies for making removable prostheses. When comparing the treatment of patients with removable plate dentures manufactured using different laboratory techniques, we can note that the greatest chewing efficacy in patients using prosthetics is made by the injection molding method $290.04 \pm 0.23 \mu \mathrm{V}$. Not significantly less masticatory efficacy in patients with prosthetics that was made by the thermo-injection method is $181.24 \pm 1.05 \mu \mathrm{V}$, and the smallest index, where the prostheses were made using the compression technique $159.21 \pm 1.03 \mu \mathrm{V}$

Thus, EMG studies have shown that the method of casting followed by polymerization under pressure in the manufacture of removable laminar prostheses restores the chewing function more qualitatively, and encourages the normalization and adaptation of the muscular system to chewing.

Keywords: removable prosthesis, adaptation, electromyography, laboratory technologies.

\section{Контактная информация}

Запара П.С. - асистент кафедри ортопедичної стоматології, Харківський національний медичний університет E-mail: stomajs@mail.ru

ORCID: 0000-0002-7183-9829

Янішен І.В. - завідувач кафедри ортопедичної стоматології, д-р мед. наук, професор, Харківський національний медичний університет

E-mail: super_opto@ukr.net

ORCID: 0000-0003-4278-5355

Федотова О.Л. - асистент кафедри ортопедичної стоматології, Харківський національний медичний університет E-mail: helennochka@i.ua

ORCID: 0000-0001-9421-9262 